\title{
Effect of Recycled Plastic Aggregates on Concrete
}

\author{
Parvesh Kumar ${ }^{1}$, Gaurav Kumar ${ }^{2}$ \\ ${ }^{1}$ M.Tech. student, Department of Civil Engineering, NNSS SAmalkha Group of Institutions, Department of Civil Engineering, Affiliated to \\ Kurukshetra University, Kurukshetra, Haryana, India
}

${ }^{2}$ HOD, Department of Civil Engineering, NNSS SAmalkha Group of Institutions, Department of Civil Engineering, Affiliated to Kurukshetra University, Kurukshetra, Haryana, India

\begin{abstract}
Solid waste management is one of the major environmental concerns in our countrynow a days. The present study covers the use or recycled plastics as replacement of coarse aggregates in concrete. The main aim of the study is to investigate the change in mechanical properties of concrete with the addition of plastics in concrete. Along with the mechanical properties, thermal characteristics of the resultant concrete is also studied. It is found that the use of plastic aggregates results in the formation of lightweight concrete. The compressive, as well as tensile strength of concrete reduces with the introduction of plastics. The most important change brought about by the use of plastics is that the thermal conductivity of concrete is reduced by using plastics in concrete. Therefore, it can be said that recycled plastics can be used for thermal insulation of buildings
\end{abstract}

Keywords: GGSBB, Thermoplastics, Hdpe

\section{Introduction}

Research concerning the use of by-products to augment the properties of concrete has been going on for many years. In the recent decades, the efforts have been made to use industry by-products such as fly ash, silica fume, ground granulated blast furnace slag (GGBS), glass cullet, etc., in civil constructions. The potential applications of industry by-products in concrete are as partial aggregate replacement or as partial cement replacement, depending on their chemical composition and grain size. The use of these materials in concrete comes from the environmental constraints in the safe disposal of these products. Big attention is being focused on the environment and safeguarding of natural resources and recycling of wastes materials. Actually many industries are producing a significant number of products which incorporate scrap (residues). In the last 20 years, a lot of works concerning the use of several kinds of urban wastes in building materials industrials process have been published. Many researches have been extended to study new kinds of wastes to investigate deeply particular aspects. The addition of wastes, apart from the environmental benefits, also produces good effects on the properties of final products. One of the new waste materials used in the concrete industry is recycled plastic. For solving the disposal of large amount of recycled plastic material, reuse of plastic in concrete industry is considered as the most feasible application. Recycled plastic can be used as coarse aggregate in concrete. However, it is important to underline that re- using of wastes is not yet economically advantageous, due to the high costs of transport and its effect on the total costs of production. Moreover, it is important not to neglect other costs, directly referable to the kind of wastes, due, in particular, to the need of measuring gas emission, during firing, and the presence of toxic and polluting elements.

\section{Background}

The growth of the world plastic industry has been enormous, from a little over 3 million tones in 1955 to 30 million tones presently (Jain et al., 1977). This figure touched 100 million tones mark in 2001 (http://www.wasteonline.org.uk)

The quantity of solid waste is expanding rapidly. It is estimated that the rate of expansion is doubled every 10 years. This is due to the rapid growth of the population as well as the industrial sector (Phaiboon and Mallika, 2007). In a report, the National Council on Public Works Improvement identified the solid-waste crisis as an area of the infrastructure with great needs for improvement (Rebeiz et al., 1993). The solid-waste crisis is important from an environmental and economical point of view.

As landfill areas are rapidly depleting, the cost of solidwaste disposal is rapidly increasing. The cost for solidwaste management was, on an average, $\$ 2.7-3.6 / \mathrm{t}$ in 1979. The cost is now more than $\$ 18 / \mathrm{t}$ and, in many localities; the cost exceeds \$90/t ("Our" 1989).

Among the solid-waste materials, plastics have received a lot of attention be cause they are generally not biodegradable. On a weight basis, there are about 10 billion $\mathrm{kg}$ of plastic wastes in the U.S. per year, which represents about $7 \%$ by weight of the total solid wastes (Thayer, 1989). However, plastic wastes are very visible, since they constitute about $30 \%$ by volume of the total solid wastes (Kline 1989). (Karim et al. 1992).

The various types of plastics in municipal wastes are Polyethylene terephthalate (PET), High density polyethylene (HDPE), Low density polyethylene (LDPE), Polypropylene(PP), Polystyrene (PS) etc. The major users of plastic are the packaging industries, consuming about $41 \%, 20 \%$ in building and construction, $15 \%$ in distribution and large industries, $9 \%$ in electrical and electronic, $7 \%$ in automotive, $2 \%$ in agriculture and $6 \%$ in other uses. (Zoorob and Suparma, 2000) 
International Journal of Science and Research (IJSR)

ISSN (Online): 2319-7064

Index Copernicus Value (2013): 6.14 | Impact Factor (2015): 6.391

\section{Material Used For Study}

Among the various types of plastics, the largest component of the plastic waste is low density polyethylene/linear low density polyethylene (LDPE) at about $23 \%$, followed by $17.3 \%$ of high density polyethylene, $18.5 \%$ of polypropylene, $12.3 \%$ of polystyrene (PS/extended PS), $10.7 \%$ polyvinyl chloride, $8.5 \%$ polythylene terephthalate and $9.7 \%$ of other type.

- Virgin polypropylene:-The virgin polypropylene fibers are $19 \mathrm{~mm}$ (3/4 in.) long fibrillated fibers. These are in slender fiber-form.

- Melted processed plastic: - The recycled plastic (melted processed) is produced by drawing molten automobile bumpers into long strands, which are cut to $28 \mathrm{~mm}(1.1$ in.) length. It is in slender fiber-form.

- Automobile shredded residue: - Automobile shredded residue comprised mainly mixed plastics and some rubber, with a maximum particle dimension of $19 \mathrm{~mm}$ (3/4 in.). It is in flake form.

- Shredded plastic:- The recycled plastic (shredded) is produced by shredding plastics obtained from a mixed plastic stream; the process yielded plastic flakes with a maximum planar dimension of $25 \mathrm{~mm}$ (1 in.). It is in flake form acrylic, nylon, high density polyethylene (HDPE), and low density polyethylene (LDPE)

- Electronic waste products:-These products are televisions and monitors to cell phones and CPUs.

- Food Waste Food: - Scraps can be turned into valuable soil amendments through the simple techniques of composting or feeding a worm box.

- Tires: - The recycled tires can be used in civil engineering applications, or combusted.

\section{Test Program}

Plastics can be degraded very slowly. Photo degradation can breakdown plastic resin, but this process can take decades. Even longer, biodegradation of plastics takes centuries.

The largest problem in recycling plastics is separating the plastics by type and number. In the current recycling system, the plastics must be separated by type. During the reprocessing of plastic containers, if the plastic is not of a uniform type, the raw plastic resin is unusable in the manufacturing industry.
Types of recycled plastics

\begin{tabular}{|c|c|c|c|c|}
\hline \begin{tabular}{|l|} 
Plastic \\
ID \\
code \\
\end{tabular} & Name of Plastic & Description & $\begin{array}{l}\text { Range of } \\
\text { Products }\end{array}$ & $\begin{array}{l}\text { Uses for Plastic made from } \\
\text { Recycled Waste Plastic }\end{array}$ \\
\hline 1 & $\begin{array}{l}\text { Polyethylene } \\
\text { terephthalate }\end{array}$ & $\begin{array}{l}\text { Clear tough } \\
\text { plastic }\end{array}$ & $\begin{array}{l}\text { Soft drink \& } \\
\text { mineral water } \\
\text { bottles }\end{array}$ & $\begin{array}{l}\text { Soft drink bottles; detergent } \\
\text { bottles; clear packaging film; } \\
\text { fleecy jackets; carpet fibers. }\end{array}$ \\
\hline 2 & $\begin{array}{l}\text { High density } \\
\text { polyethylene } \\
\text { (HDPE) }\end{array}$ & $\begin{array}{l}\text { Usually } \\
\text { white or } \\
\text { colored. } \\
\text { Very } \\
\text { common } \\
\text { plastic }\end{array}$ & $\begin{array}{l}\text { Milk, cream, } \\
\text { shampoo and } \\
\text { cleaner } \\
\text { bottles; milk } \\
\text { crates; freezer } \\
\text { bags. }\end{array}$ & $\begin{array}{l}\text { Compost bins; Mobile } \\
\text { garbage bins; agricultural } \\
\text { pipes. }\end{array}$ \\
\hline 3 & $\begin{array}{l}\text { Unplasticised } \\
\text { polyvinyl chloride } \\
\text { (UPVC) } \\
\text { Plasticized } \\
\text { polyvinyl chloride } \\
\text { (PPVC) }\end{array}$ & \begin{tabular}{|l|} 
Hard rigid \\
plastic may \\
be clear. \\
Flexible \\
clear \\
elastic \\
plastic.
\end{tabular} & \begin{tabular}{|l|} 
Clear cordial \& \\
juice bottles: \\
plumbing \\
fittings \\
Garden hoses, \\
shoe soles.
\end{tabular} & $\begin{array}{l}\text { Detergent bottles; hoses; tiles; } \\
\text { plumbing pipes \& fittings. }\end{array}$ \\
\hline 4 & $\begin{array}{l}\text { Low density } \\
\text { polyethylene } \\
\text { (LDPE) }\end{array}$ & $\begin{array}{l}\text { Soft, } \\
\text { flexible } \\
\text { plastic. }\end{array}$ & $\begin{array}{|lr|}\text { Garbage } & \text { bags, } \\
\text { black } & \text { plastic } \\
\text { sheet; } & \text { ice- } \\
\text { cream container } \\
\text { lids. }\end{array}$ & $\begin{array}{l}\text { Film \& bags for building and } \\
\text { packaging. }\end{array}$ \\
\hline 5 & $\begin{array}{l}\text { Polypropylene } \\
\text { (PP) }\end{array}$ & $\begin{array}{l}\begin{array}{l}\text { Hard but } \\
\text { flexible } \\
\text { plastic }\end{array} \\
\end{array}$ & $\begin{array}{l}\text { Ice-cream } \\
\text { containers, } \\
\text { drinking straws, } \\
\text { potato crisp } \\
\text { bags. }\end{array}$ & $\begin{array}{l}\text { Compost bins; Kerbside } \\
\text { recycling crates. }\end{array}$ \\
\hline 6 & \begin{tabular}{|l} 
Polystyrene (PS) \\
Expanded \\
polystyrene (UPS)
\end{tabular} & $\begin{array}{|ll|}\text { Rigid, } & \\
\text { brittle } & \\
\text { plastic. } & \\
\text { May } & \text { be } \\
\text { clear } & \text { or } \\
\text { glassy. } & \\
\end{array}$ & \begin{tabular}{|l|} 
Yoghurt \\
containers; \\
plastic cutlery. \\
Hot drink \\
cups; meat \\
trays; \\
packaging.
\end{tabular} & $\begin{array}{l}\text { Clothes pegs, coat hangers, } \\
\text { video \& CD boxes. }\end{array}$ \\
\hline
\end{tabular}

Advantages of using plastics in concrete The growth in the use of plastic is due to its beneficial properties, which include:

1) Extreme versatility and ability to be tailored to meet specific technical needs.

2) Lighter weight than competing materials reducing fuel consumption during transportation.

3) Durability and longevity.

4) Resistance to chemicals, water and impact.

5) Excellent thermal and electrical insulation properties.

6) Comparatively lesser production cost.

\section{Disadvantages of plastics}

The followings are the main disadvantages of using the plastics in concrete are as follows:-

1) Plastics are having low bonding properties so that the strength of concrete gets reduced such as compressive, tensile and flexural strength.

2) Its melting point is low so that it cannot be used in furnaces because it gets melt as its comes in contact with the heat at high temperature.

\section{Result and Discussion}

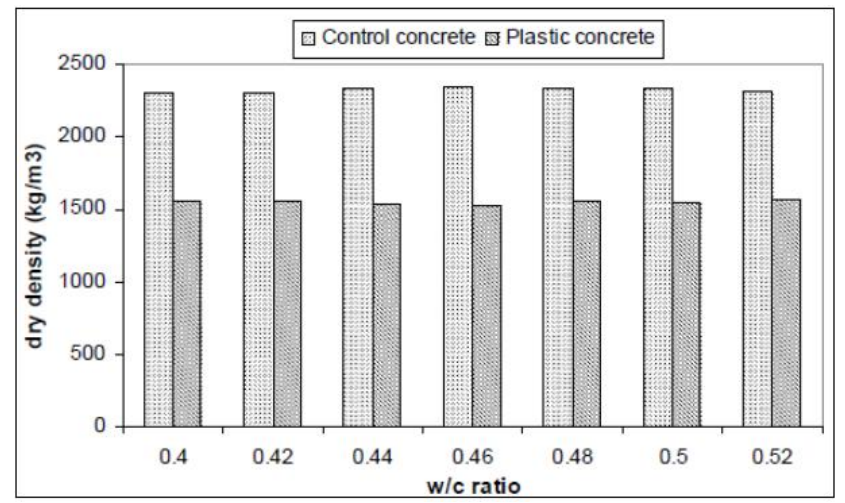

Graph between w/c ratio and dry density of control concrete and plastic replaced concrete

\section{Volume 5 Issue 6, June 2016} www.ijsr.net 
International Journal of Science and Research (IJSR)

ISSN (Online): 2319-7064

Index Copernicus Value (2013): 6.14 | Impact Factor (2015): 6.391

Compressive strength of control and plastic added concrete

\begin{tabular}{|c|c|c|c|}
\hline $\begin{array}{c}\text { w/c } \\
\text { Ratio }\end{array}$ & \multicolumn{2}{|c|}{$\begin{array}{c}\text { Compressive } \\
\text { strength }\end{array}$} & \multirow{2}{\text{Percentagereduction}}{$\begin{array}{c}\text { MPa) } \\
\text { in compressive } \\
\text { strength (\%) }\end{array}$} \\
\cline { 2 - 3 } & $\begin{array}{c}\text { control } \\
\text { concrete }\end{array}$ & $\begin{array}{c}\text { plastic } \\
\text { concrete }\end{array}$ & \\
\hline 0.40 & 39.67 & 13.09 & 67.00 \\
\hline 0.42 & 38.63 & 11.39 & 70.51 \\
\hline 0.44 & 38.47 & 10.65 & 74.24 \\
\hline 0.46 & 37.74 & 10.21 & 72.94 \\
\hline 0.48 & 35.37 & 9.96 & 71.84 \\
\hline 0.50 & 32.11 & 9.44 & 70.60 \\
\hline 0.52 & 27.67 & 10.06 & 63.64 \\
\hline
\end{tabular}

The thermal analysis was carried out on both the control concrete and concrete made by replacing $100 \%$ coarse aggregate with plastic aggregates. The water cement ratio was taken as $0.4,0.42,0.44,0.46,0.48,0.50$, and 0.52 . The thermocouples were made with the copper and constantan wires connected with the ends by welding or shouldering. The test set up is explained in Chapter 3. The emf of the centre of the cube is obtained by using copper-Constantine thermocouple. The emf is then converted into temperature by using the following expression:

Temperature Conversion Equation:

$$
\mathrm{T}=\mathrm{a} 0+\mathrm{a} 1 \mathrm{x}+\mathrm{a} 2 \mathrm{x} 2+\ldots+\mathrm{anxn} \ldots(4.1)
$$

This equation can be expanded to have the polynomial equation of the form:

Nested Polynomial Form:

$$
\mathrm{T}=\mathrm{a} 0+\mathrm{x}(\mathrm{a} 1+\mathrm{x}(\mathrm{a} 2+\mathrm{x}(\mathrm{a} 3+\mathrm{x}(\mathrm{a} 4+\mathrm{a} 5 \mathrm{x}))))
$$

(5th order) ..

where $\mathrm{x}$ is in Volts, $\mathrm{T}$ is in ${ }^{\circ} \mathrm{C}$

The value of constants for Copper- Constantine thermocouple is stated as under: $\mathrm{a} 0=0.100860910$

a1 $=25727.94369$

85

$\mathrm{a} 2=-767345.8295 \mathrm{a} 3=78025595.81 \mathrm{a} 4=-9247486589$

$\mathrm{a} 5=6.97688 \mathrm{E}+11 \mathrm{a} 6=-2.66192 \mathrm{E}+13 \mathrm{a} 7=3.94078 \mathrm{E}+1$

Therefore, the equation for Copper- Constantine thermocouple can also be written as:

$\mathrm{T}=0.100860910+\mathrm{x}(25727.94369+\mathrm{x}(-767345.8295+\mathrm{x}($ $78025595.81+\mathrm{x}(-9247486589+\mathrm{x}(6.97688 \mathrm{E}+11+\mathrm{x}(-$ $2.66192 \mathrm{E}+13+3.94078 \mathrm{E}+14 \mathrm{x})$

Internal temperature of concrete cube when normal aggregates are used

\begin{tabular}{|c|c|c|c|}
\hline $\begin{array}{c}\text { w/c } \\
\text { Ratio }\end{array}$ & $\begin{array}{c}\text { emf of } \\
\text { Junction } \\
\text { J1 }\end{array}$ & $\begin{array}{c}\text { Temperature } \\
\text { of Junction J1 }\end{array}$ & $\begin{array}{c}\text { Time required } \\
\text { to reach constant } \\
\text { emf (hours) }\end{array}$ \\
\hline 0.40 & 0.0010 & 25.13 & 3 hours \\
\hline 0.42 & 0.0010 & 25.13 & 3 hours, $20 \mathrm{~min}$. \\
\hline 0.44 & 0.0010 & 25.13 & 3 hours, $50 \mathrm{~min}$ \\
\hline 0.46 & 0.0011 & 27.26 & 3 hours, $40 \mathrm{~min}$. \\
\hline 0.48 & 0.0012 & 29.29 & 4 hours, $10 \mathrm{~min}$ \\
\hline 0.50 & 0.0012 & 29.29 & 4 hours, $10 \mathrm{~min}$. \\
\hline 0.52 & 0.0012 & 29.29 & 4 hours, 30 min \\
\hline
\end{tabular}

Split tensile strength of control concrete and plastic

\begin{tabular}{|c|c|c|c|}
\hline \multirow[t]{2}{*}{$\begin{array}{c}\mathbf{w} / \mathbf{c} \\
\text { Ratio }\end{array}$} & \multicolumn{2}{|c|}{$\begin{array}{c}\text { Tensile } \\
\text { strength (MPa) }\end{array}$} & \multirow{2}{*}{$\begin{array}{c}\text { Percentage } \\
\text { reduction in } \\
\text { tensile strength } \\
(\%)\end{array}$} \\
\hline & $\begin{array}{l}\text { Control } \\
\text { concrete }\end{array}$ & $\begin{array}{l}\text { Plastic } \\
\text { concrete }\end{array}$ & \\
\hline 0.40 & 3.98 & 1.13 & 71.6 \\
\hline 0.42 & 3.95 & 1.08 & 72.7 \\
\hline 0.44 & 3.92 & 0.8 & 79.6 \\
\hline 0.46 & 3.77 & 0.79 & 79.1 \\
\hline 0.48 & 3.67 & 0.76 & 79.3 \\
\hline 0.50 & 3.28 & 0.75 & 77.1 \\
\hline 0.52 & 3.04 & 0.74 & 75.7 \\
\hline
\end{tabular}
concrete

\section{Conclusion}

Following are the conclusions can be made based upon the studies made by various researchers:-

1) Plastics can be used to replace some of the aggregates in a concrete mixture. This contributes to reducing the unit weight of the concrete. This is useful in applications requiring nonbearing lightweight concrete, such as concrete panels used in facades.

2) For a given w/c, the use of plastics in the mix lowers the density, compressive strength and tensile strength of concrete.

3) The effect of water-cement ratio of strength development is not prominent in the case of plastic concrete. It is because of the fact that the plastic aggregates reduce the bond strength of concrete. Therefore, the failure of concrete occurs due to failure of bond between the cement paste and plastic aggregates.

4) Introduction of plastics in concrete tends to make concrete ductile, hence increasing the ability of concrete to significantly deform before failure. This characteristic makes the concrete useful in situations where it will be subjected to harsh weather such as expansion and contraction, or freeze and thaw.

5) The inclusion of recycled aggregates in the concrete of the buildings under investigation has been shown to be advantageous from an energy point of view. The use of plastic aggregates helped in keeping the interior cooler, when the outside temperature is raised, as compared to the corresponding control concrete

\section{References}

[1] Al-Manaseer, A.A., T.R., Dalal.,1997. "Concrete containing plastic aggregates", Concrete International, 47-52.

[2] Ashraf, M., Ghaly, F., 2004. ASCE,1 and Michael S. Gill, A.M.ASCE2 "Journals of materials in civil engineering' (C) ASCE, 289-296.

[3] Balaguru, P.N., Shah, S.P., 1992., "Fiber Reinforced Cement Composites". McGraw- Hill, Inc., 530 p.

[4] Batayneh, M., Marie, I., Asi I., 2006. "Use of selected waste materials in concrete mixes". Waste Management (27) 1870-1876 


\section{International Journal of Science and Research (IJSR) \\ ISSN (Online): 2319-7064}

Index Copernicus Value (2013): 6.14 | Impact Factor (2015): 6.391

[5] Bayasi, Z., Zeng, J., 1993.” Properties of polypropylene fiber reinforced concrete". ACI Materials Journal 90 (6), 605-610.

[6] Benazzouk, A., Queneudec, M.., 2002. "Durability of cement-rubber composites under freeze thaw cycles". Proceedings of the International Conference on Sustainable Concrete Construction, University of Dundee, Scotland, UK, pp. 356-362

[7] Boutemeur, R., Taibi, M., Ouhib, N., Bali, A., 2004. "Investigation of the use of waste plastic as aggregate for concrete" In: International Conference, Sustainable Waste

[8] Management and Recycling: Challenges and Opportunities, 14-15. Thomas Telford Publishing, Thomas Telford Ltd., London, ISBN 0727732854.

[9] Cheong, K. H. and Lee, S. C., 1993. "Strength of Retempered Concrete", ACI Materials

\section{Author Profile}

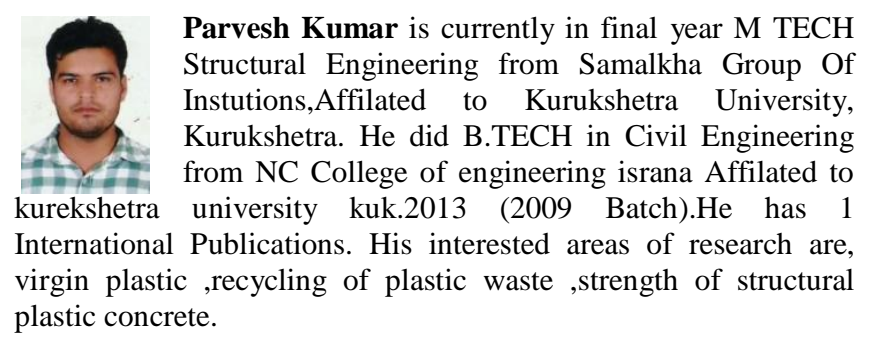

Volume 5 Issue 6, June 2016 www.ijsr.net 